\title{
Turista a turizmus ako metafory pohybu a pobytu človeka $v$ modernej spoločnosti. K niektorým vybraným koncepciám sociológie turizmu
}

\author{
The Tourist and Tourism as Metaphors of Mobility and Existence \\ of a Human in the Modern Society: Towards some Selected \\ Concepts of the Sociology of Tourism
}

\author{
Ivan Chorvát
}

\begin{abstract}
The paper reflects the significance of travel and tourism in the contemporary society as it appears in works of sociologists dealing with the topic of tourism. It traces the origins and preconditions of the organized tourism (the transformation from the "traveller" to the "tourist") and its institutionalization in the 19th century. The paper then traces the origins and continuations of the sociology of tourism as a sociological discipline from its beginnings in the 1970s until now, and distinguishes between two main approaches to the study of tourism - the professional perspective and the academic perspective. Some principal authors and their views are presented, such as the dispute over MacCannell's concept of authenticity (some notions of authenticity - objective, constructive and existential - are highlighted), Urry's concept of the tourist gaze and his view of mobility, and Bauman's notion of the tourist syndrome. In the conclusion the idea of tourism as emblematic of many features of contemporary life is stressed.
\end{abstract}

KEY WORDS authenticity, democratization of travel, sociology of tourism, tourist, tourist gaze, tourist syndrome, traveller

V súčasnom svete sme všetci turistami, niektorí viac, iní menej, všetci však aspoň trochu, a to nielen počas prázdnin a dovoleniek. Takéto a podobné myšlienky sa objavujú vo viacerých prácach Zygmunta Baumana či Johna Urryho. Michel Maffesoli vo svojej práci $O$ nomádství píše o návrate pudu blúdenia, $\mathrm{v}$ dôsledku ktorého sa z každého stáva cestovatel' neustále hladajúci nejaké „inde“ (Maffesoli 2002). Aj pre mnohých iných autorov je turista modelom pre moderného človeka vo všeobecnosti (MacCannell 1976) a turizmus tým, čo stelesňuje u moderného človeka hl'adanie zmyslu a stáva sa symbolom sveta, v ktorom žijeme (Crick 1996). V tomto texte sa pokúsime reflektovat' význam cestovania a turizmu v súčasnej západnej spoločnosti prostredníctvom koncepcií a teórií, ktoré nám môže sprostredkovat' sociológia turizmu ako v rámci sociológie relatívne nová a zatial' nie natol'ko rozšírená disciplína.

Sociální studia. Fakulta sociálních studií Masarykovy univerzity, 1/2006. S. 111-128. ISSN 1214-813X.

Tento príspevok je súčast’ou grantového projektu VEGA č. 1/2493/05 „Fenomén cestovného ruchu (turizmu) v súčasnej spoločnosti - sociologická analýza“. 


\section{Od cestovatel'a k turistovi}

Aj ked' cestovanie je významným fenoménom modernej spoločnosti a ako masový jav sa rozvíja až v 20. storočí, nie je niečím, čo by sa netýkalo spoločnosti v minulosti. L'udia cestovali vždy, o čom dodnes svedčia zvyšky ciest vybudovaných napríklad už v období antického Ríma. Na cesty sa vydávali vojaci, kupci, pútnici, poslovia, rytieri, tovariši, študenti, bedári, králi i pápeži, len vel'mi zriedka sa však l’udia vyberali na prázdninové cesty a cestovanie pre radost' bolo výsadou vyhradenou len vel'mi obmedzenému počtu l'udí. Nikoho z nich nemôžeme označit' ako turistu, turista je postavou výhradne modernou (Verdon 2003, Bauman 1993a).

Turizmus v modernom chápaní je pravdepodobne britským vynálezom. ${ }^{1}$ Za predchodcov turistov (v zmysle istej inštitucionalizácie cestovania) môžeme považovat' mladých britských aristokratov, ktorí sa vydávali na „kontinent“ už od dôb renesancie v rámci takzvaných Grand Tours, a táto forma cestovania nadobudla $\mathrm{v}$ aristokratických kruhoch vel'kú popularitu v 18. storočí. Cielom ciest do hlavných centier európskej kultúry a vedenia bolo praktické spoznávanie kultúry, minulosti a sociopolitickej súčasnosti vtedajšieho „civilizovaného“ sveta. Išlo o akési ukončenie, vyvrcholenie a skompletizovanie vzdelania mladých príslušníkov šlachtického stavu. Sprievodným javom tohto procesu a nemenej dôležitým výsledkom mal byt' tiež rozvoj osobnosti a nadobudnutie životnej skúsenosti mladého cestovatela (Berghoff a Korte 2002). Cestovanie v tomto i predchádzajúcich obdobiach tak malo len málo spoločné s oddychom a potešením a muselo byt' legitimizované nejakými vážnejšími, užitočnejšími a praktickejšími ciel'mi. Chloe Chard (2002) píše, ako ku koncu 18. storočia cestovanie prestávalo byt' späté výhradne so vzdelaním a začalo zahŕňat aj nový romantický obsah, ktorý sa viazal jednak na obdiv tých artefaktov, ktoré boli predmetom záujmu už počas Grand Tours, ale navyše sa sústred’oval aj na krásy prírody a krajiny, s ktorými bolo romantické cestovanie predovšetkým spájané. John Urry v podobnom duchu poukazuje na vzrastajúcu vizualizáciu cestovatel'skej skúsenosti a na to, ako sa postupne posúval dôraz od predchádzajúcej „klasickej Grand Tour“ založenej na emocionálne-neutrálnom pozorovaní a zaznamenávaní galérií, múzeí a artefaktov vysokej kultúry, k „romantickej Grand Tour“ 19. storočia, ktorá sa vyznačovala objavením ,scénického turizmu“ a ovel’a privátnejším a emocionálnejším prežívaním krás a zaujímavostí (Urry 1991: 4).

Aj preto sa slovo turista (tourist) objavuje najskôr $\mathrm{v}$ angličtine, a to práve koncom 18. storočia. ${ }^{2}$ Výraz turizmus sa prvýkrát vyskytuje vo vydaní Oxford English Dictionary z roku 1811 (Berghoff a Korte 2002). Devätnáste storočie je obdobím, ked’ začína byt predchádzajúci cestovatel' ako zvláštny typ človeka - pre ktorého je cestovanie privilégiom, osudom alebo špecific-

H. Berghoff a B. Korteová (2002) zdôrazňujú, že aj ked’ významný rozvoj turizmu nastal v 19. a 20. storočí, kultúrne predpoklady tohto vývoja boli založené už v predchádzajúcich storočiach. „Zrod moderného turizmu bol dlhotrvajúcim procesom, hlboko zakoreneným v kultúrnej a intelektuálnej, ekonomickej a sociálnej histórii Británie“(2002: 4). Proces vzniku a vývoja moderného turizmu je dôkladne analyzovaný v Berghoff a kol. (2002).

2 Prvý raz bolo slovo „turista“ použité v sprievodcovi oblast'ou Lake District v severnom Anglicku v roku 1780. V knihe o využívaní nových anglických slov vydanej v roku 1800 bolo napísané: „Cestovatel' sa dnes nazýva turistom“ (citované podl’a Sharpley 1994: 63). 
kým zdrojom obživy a cestuje takpovediac z objektívnych dôvodov - nahradzovaný turistom, ktorý sa vyskytuje $\mathrm{v}$ ovel'a hojnejšom počte a cestuje kvôli potešeniu, zo subjektívnych príčin. Aj ked' spočiatku sa výrazy cestovatel' a turista použivali zamenitelne, postupne sa začalo medzi nimi rozlišovat'. Výstižným spôsobom reflektuje tento rozdiel Daniel Boorstin (1964) vo svojej známej eseji, v ktorej sa venuje „stratenému umeniu cestovania“ a tomu, ako sa v priebehu 19. a 20. storočia z cestovatel'a stal turista. Cestovatel'a spája s aktivitou, poukazuje na to, ako si jeho cestovanie vyžadovalo dlhé plánovanie, výdavky, značnú časovú investíciu, zahŕňalo zdravotné riziká a často aj ohrozenie života. Cestovatel' počas svojich ciest vyhl'adával stretnutia s l’ud’mi, vlastným pričinením zažíval dobrodružstvá a zážitky a nadobúdal skúsenosti. Turista je však pasívny, očakáva, že sa mu prihodia zaujímavé veci, že všetko bude pre neho zabezpečené. „Cestovanie prestáva byt' aktivitou... a stáva sa komoditou.“ Cestovatel’ sa mení na turistu vtedy, ,....ked' sú atraktívne zložky cestovania zabalené a predávané v balíčkoch (package tour). Zakúpením cesty si môžete zaviazat' niekoho iného, aby zariadil, že sa Vám prihodia príjemné a zaujímavé veci“ (Boorstin 1964: 85).

Túto premenu podmienili procesy, ktoré súviseli s priemyslovou revolúciou, industrializáciou a urbanizáciou, rozvojom hromadnej (predovšetkým železničnej) dopravy, oddelením pracovného času od vol'ného času, zvýšením príjmov širších vrstiev najmä v industriálnych oblastiach, výraznejšou triednou diferenciáciou obyvatel'stva a s tým súvisiacou priestorovou (rezidenčnou) separáciou jednotlivých tried a vrstiev mestského obyvatel'stva. K rozvoju turizmu v 19. storočí však rozhodujúcou mierou prispela aj jeho inštitucionalizácia spojená s organizovaním hromadných zájazdov. Ako si všíma R. Sharpley (1994: 49-51), medzi novou viktoriánskou strednou triedou neexistovala tradícia cestovania, väčšina l'udí nemala predstavu, ako prekonávat' potenciálne problémy spojené s cestovaním doma i v cudzine - jazykové bariéry, výmenu peňazí, to, kam najlepšie íst' či kde sa ubytovat'. Priekopníkom v ponuke a propagácii organizovaných zájazdov bol Thomas Cook, ${ }^{3}$ ktorý reagoval na potrebu vzniku organizácie zabezpečujúcej turistom pri ich cestách všetky služby a pomoc. Začínal organizovaním špeciálnych vlakových výletov po Anglicku začiatkom 40. rokov 19. storočia, ${ }^{4} \mathrm{v}$ roku 1848 rozšríil exkurzie do Škótska, jeho vel'kým úspechom bola svetová výstava v Londýne v roku 1851, kam sa mu podarilo dopravit' 165000 návštevníkov. Čoskoro sa súčastou zájazdov stali zdvorilí a vzdelaní sprievodcovia, systém hotelových kupónov, možnost' rezervácie izieb, ochrana a poradenstvo proti chorobám a krádežiam. V roku 1856 ponúkala cestovná kancelária Thomas Cook a syn prvú vel'kú okružnú cestu po európskom kontinente, s návštevou Antverp, Bruselu, Waterloo, Kolína, údolia Rýna, Frankfurtu, Heidelbergu, Baden-

3 Ojedinelé pokusy o organizované výlety sa vyskytli už pár rokov pred tým, ako Thomas Cook založil so synom svoju cestovnú agentúru. D. Boorstin (1964: 87) uvádza, že údajne prvý ,zájazd““ bol zorganizovaný v roku 1838. Špeciálny vlak viezol l'udí z Wadebridge do blízkeho mestečka Bodmin, kde sledovali popravu dvoch vrahov obesením.

4 T. Cook bol vel'kým podporovatel'om striedmeho spôsobu života. Ked' raz kráčal na stretnutie spolku striedmosti v Leicestri, napadlo ho, že by mohol zorganizovat' špeciálny vlak, ktorý by na určené miesto dopravil väčší počet prívržencov tohto hnutia. Dňa 5. júla 1841 zorganizoval svoj prvý zájazd z Leicestru do Loughborough. Pät'stosedemdesiat účastníkov cestovalo 11 míl' vlakom na stretnutie abstinentov, za spiatočný lístok zaplatili jeden šiling (Sharpley 1994: 49-50). 
Badenu, Štrasburgu, Paríža, Le Havre a odtial' naspät' do Londýna. Nasledovali cesty do Švajčiarska, lodnou dopravou do Ameriky i Svätej zeme. V roku 1872 už bola v ponuke prvá cesta okolo sveta. Thomas Cook uskutočnil revolúciu v cestovaní, premenil ho z výsady mála privilegovaných na medzinárodný priemysel a vytvoril tzv. baličkový zájazd (package tour), ktorý sa neskôr stal najpopulárnejším produktom turistického odvetvia a klúčom ku skutočnej demokratizácii cestovania (Boorstin 1964, Sharpley 1994). ${ }^{5}$

Demokratizácia cestovania sa však nestretla len s pozitívnymi reakciami. Vzdelaní Angličania $\mathrm{z}$ aristokratických vrstiev namietali, že Cook zbavuje cestovatel'ov iniciatívy a dobrodružstva. Básnik a filozof John Ruskin napísal: „Cestu vlakom nepovažujem za cestovanie, je to len akési poslanie človeka na nejaké miesto, v podstate sa neodlišujúce od skúsenosti byt' balíkom“ (citované podl'a Boorstin 1964: 87). A britský konzul v Taliansku uverejnil v roku 1865 článok v Blackwood's Magazine, kde o turistoch Thomasa Cooka s neskrývaným pohŕdaním píše: „Talianske mestá sú preplnené stádami týchto kreatúr, pretože sa od seba nikdy neoddelia. Vidíme ich, ako sa štyridsiati v kope vláčia ulicami aj so svojím vedúcim, ktorý sliedi okolo nich, raz vpredu, raz vzadu, ako pastiersky pes..." (tamtiež: 88). V týchto riadkoch je nepochybne vyjadrená predpokladaná neautenticita skúsenosti turistov, o ktorú ich oberá $\mathrm{v}$ tých časoch sa rozvíjajúca masová doprava a inštitucionalizácia cestovania. K téme autenticity ako jednej z klúčových tém sociológie turizmu sa ešte vrátime $v$ jednej z d’alších častí textu.

Na tomto mieste bude vhodné učinit' dve terminologické poznámky. Prvá sa vzt'ahuje na používanie pojmu cestovatel' (traveller) v súčasnosti. Týka sa jednak privátnych, neinštitucionalizovaných (alebo poloinštitucionalizovaných) foriem cestovania, ktoré majú výrazne individuálny charakter; ich emblémom sú tí, ktorí cestujú s batohom na chrbtoch - „,backpackers“ (Sørensen 2003, Bell 2002). Významným fenoménom najmä v Británii sú tiež tzv. „New Age Travellers", akísi novodobí kočovníci, pre ktorých je cestovanie filozofiou, spôsobom života a ktorí si vedome volia slobodu nemat’ domov. Ako však upozorňuje Martin (2002), zvýrazňovanie momentu slobodnej vol'by u autorov analyzujúcich tento fenomén často zastiera fakt, že u vel'kej časti „New Age Travellers“ ide do značnej miery o vynútenú vol'bu, spôsob, akým sa vyhnút' bezdomovectvu či squatterskému spôsobu života.

Ciel’om druhej poznámky je upozornit' aj na iný, pôvodnejší význam termínu turista v českom i slovenskom kontexte. Na rozdiel od masového pasívneho turistu inšitucionalizovaného vo sfére turizmu bol v našom priestore turista tradične chápaný ako niekto, kto sa zaoberá turistikou, tj. aktívnym pohybom a pobytom v prírode, spoznávajúc vlastnú krajinu, jej prírodné krásy i kultúrne dedičstvo. Výsledkom oblúbenosti týchto aktivít v českých krajinách bolo založenie Klubu českých turistů už v roku 1888, s prvým predsedom V. Náprstkom, známym cestovatel'om a verejným činitel'om. Na Slovensku mala turistika taktiež tradíciu, turistická činnost'

Demokratizácia cestovania neznamená, že cestovanie prestáva byt' znakom sociálneho statusu. Je nad’alej sociálne selektívnym. S rozvojom dopravných technológií, ktoré umožnili masové cestovanie, sa však už statusový rozdiel nevedie natol'ko medzi tými, ktorí cestujú a ktorí necestujú, ale medzi rôznymi typmi či triedami turistov, respektíve medzi destináciami, ktoré rôzni turisti vyhladávajú. Neskôr, v 20. storočí, to bolo najskôr auto a potom i lietadlo, ktoré d’alej demokratizovali geografický pohyb (Urry 1991: 16). 
bola charakteristická hlavne v oblasti Vysokých Tatier a organizovaná turistika sa rozvíjala od začiatku 80. rokov 19. storočia v rámci jednotlivých regionálnych sekcií Uhorského karpatského spolku. Vznikom I. ČSR v roku 1918 a pričlenením slovenských turistov sa Klub českých turistů transformoval na Klub československých turistov. Na rozvoj turistiky v našich krajinách vplývali i myšlienky skautingu a trampingu, ktorý vznikol spontánne po roku 1918 ako špecifická česko-slovenská forma pobytu v prírode. Našim ciel'om v tejto stati však nie je podrobnejšie mapovat' historický vývoj česko-slovenského turistického hnutia, len poukázat' na významové odtiene používania výrazu turista $v$ našom kontexte.

\section{Sociológia turizmu - počiatky a problémy}

Je nepochybné, že to bol rozvoj modernej industriálnej spoločnosti, ktorý vytvoril podmienky a predpoklady pre masové cestovanie a turizmus. Ten už nie je len osobnou potrebou a záujmom, individuálnym hobby; dovolenka mimo miesta bydliska nie je len spoločensky akceptovatel'nou zložkou života, ale niečím vyžadovaným, pre zdravie a duševnú pohodu nevyhnutným. Stal sa motívom produkovaným spoločnost'ou, ,sociálnou terapiou, bezpečnostným ventilom umožňujúcim udržiavat' každodenný svet v pracovnom tempe. Pomáha stabilizovat' nielen jedinca, ale celú spoločnost' a ekonomiku““ (Krippendorf 1986: 525). ${ }^{6}$

Preto je prekvapujúce, aká malá pozornost' sa venuje problematike cestovania a turizmu v sociológii. Turizmus je najväčším pohybom l’udí na svete, tvorí jednu dvanástinu svetového obchodu a desatinu svetovej zamestnanosti i hrubého národného produktu v globálnom meradle (Urry 2002b: 257). „Dnes je takmer každá komunita a národ, vel’ký či malý, rozvinutý či rozvíjajúci sa, do určitej miery ovplyvňovaný turizmom“ (Jafari 1982: 137). Nesmierny význam tohto odvetvia je v súčasnosti samozrejmost'ou, stále sa však zdôrazňuje predovšetkým jeho ekonomický prínos oproti sociálnej, kultúrnej a politickej významnosti tohto fenoménu. Problematika cestovného ruchu sa od 40. rokov 20. storočia študovala hlavne v rámci ekonómie a geografie, až od 70. rokov sa začali vo väčšej miere objavovat' vo svete sociologické štúdie zamerané na turizmus a ešte aj v súčasnosti je sociológia turizmu v rámci sociológie $\mathrm{v}$ podstate marginálnou disciplínou. $\mathrm{V}$ polovici 90. rokov, v knihe nazvanej Sociology of Tourism (Sociológia turizmu), sa konštatovalo, že ,neexistuje žiadna učebnica akademického charakteru, ktorá by v obsiahlejšom meradle postihovala sociologické dimenzie turizmu“ (Apostolopoulos a kol. 1996: xiii). Situácia sa nezmenila ani desat'ročie od publikovania tohto tvrdenia.

6 Turizmus je často identifikovaný s re-kreáciou, tj. znovuvytváraním, znovuobnovovaním, „dobíjaním bateriek“, čo je nevyhnutné pre udržiavanie mentálneho a telesného zdravia - jedinca, ako aj celej spoločnosti. Zdá sa byt' preto spoločenským rituálom, ked’že „vychádza z presvedčenia o inštrumentálnej hodnote a účinkoch určitých praktík, ktorých ritualizácia túto vieru podporuje“ (Velký sociologický slovník 1996: 939) Turizmus preto z hl'adiska celku plní výrazné integračné funkcie (čo je funkcia rituálu, zdôrazňovaná Durkheimom) a je tiež ,nástrojom, pomocou ktorého spoločnost' udržuje a upevňuje svoje normatívne usporiadanie a organizáciu“ (VSS 1996: 938, heslo „rituál“). 
U nás (na Slovensku i v Českej republike) sa cestovnému ruchu venuje pozornost' v rámci ekonómie (v menšej miere i v geografii), tento pohl'ad však abstrahuje od problémov sociálneho a kultúrneho charakteru a cestovný ruch vidí len ako súbor ekonomických aktivít, zameriava sa na politiku cestovného ruchu, $\mathrm{v}$ rámci ktorej sa orientuje na identifikovanie a prispôsobovanie ekonomických indikátorov. V slovenskej sociológii problematika turizmu prakticky nie je reflektovaná, českí sociológovia sa jej venujú okrajovo, lepšia situácia je v pol’skej sociológii, čo však platí pre viaceré odvetvia sociologického skúmania, nielen pre turizmus. ${ }^{7}$

Podla Apostolopoulosa a kol. (1996) je možné skúmat' cestovný ruch/turizmus z hl'adiska dvoch perspektív. Prvou je profesionálna perspektíva, ktorá preferuje štúdium a aplikáciu cestovného ruchu ako jedného z odvetví národného hospodárstva. Pomocou poznatkov získaných takýmto štúdiom je potom možné cestovný ruch úspešnejšie riadit', propagovat' a tiež vyhodnocovat' a uspokojovat' potreby trhu cestovného ruchu. Jej ciel'om je vychovávat' kvalifikovaných odborníkov, ktorí budú úspešne pôsobit' ako profesionáli v odvetví cestovného ruchu. Tento prístup sa do vel'kej miery kryje so zmieňovanou ekonomickou líniou a aj vo svete je zastúpený väčšinovo.

Zatial' menej frekventovaným je akademický prístup. Ten kladie dôraz na štúdium turizmu ako nesmierne podnetného sociálneho fenoménu, ktorého analýza nám môže poodhalit' vel'a z podmienok a dôsledkov modernity a ponúknut' klúč k pochopeniu mnohých problémov modernej spoločnosti. Akademický prístup zdôrazňuje potrebu opísat', objasnit' a porozumiet' fenoménu turizmu a ponúknut' teoretický náhl'ad, ktorý prekračuje okamžitú praktickú potrebu cestovného ruchu ako ekonomického odvetvia. Tento text vychádza z akademického prístupu a snaží sa poukázat' na potrebu práve takéhoto spôsobu analýzy v snahe o sociologické uchopenie fenoménu turizmu v súčasnej spoločnosti. ${ }^{8}$

7 Témy týkajúce sa turizmu vo svojej práci reflektovala česká sociologička Hana Librová (1994: 65-75). Problematiku turizmu a autenticity akcentovala Marie Valentová (2001). V Pol'sku sa sociologickým aspektom turizmu venujú niekol'kí autori, najvýznamnejším z nich je Krzysztof Przecławski, autor viacerých prác z oblasti sociológie a filozofie turizmu (Przeclawski 1979, 1984, 1996).

8 Na tomto mieste bude vhodné vyjadrit' sa $\mathrm{k}$ terminológii a prispiet' $\mathrm{k}$ pojmovému vyjasneniu výrazov „turizmus“ a „cestovný ruch“. Slovenskí odborníci na cestovný ruch, tj. prevažne ekonómovia a marketingoví špecialisti, majú už roky zaužívaný pojem „,cestovný ruch“, výraz „turizmus“ nepovažujú za správny. V kontexte ekonomického alebo tzv. profesionálneho prístupu, ktorý cestovným ruchom rozumie ,súbor činností zameraných na uspokojovanie potrieb súvisiacich s cestovaním a pobytom osôb mimo miesta trvalého bydliska a zvyčajne vo vol’nom čase“(Gúčik a kol. 2004: 18), je možné používanie pojmu ,cestovný ruch“ považovat' za adekvátne a správne. Ked” však uvažujeme o cestovnom ruchu zo širšieho hl'adiska, nielen ako o súbore činností zabezpečujúcich potreby subjektov cestovného ruchu, ak ho vnímame v súlade s akademickým prístupom ako sociokultúrny fenomén, ak ho skúmame v prepojení s inými oblast’ami sociologického skúmania - napríklad s oblast’ou práce, vol'ného času, životného štýlu, spotreby, masovej kultúry, mobility -, ak skúmame jeho sociokultúrne vplyvy, pod ktoré Cohen (1984: 385) okrem iného zahŕňa interpersonálne vzt’ahy, spoločenskú organizáciu komunitných vzt’ahov, rytmus sociálneho života, migráciu, del'bu práce, sociálnu stratifikáciu, zvyky a prezentáciu miestnej kultúry, zvykov a tradícií, tak potom úzko, odvetvovo či takpovediac industriálne chápaný pojem „,estovný ruch““ označujúci súbor služieb je vhodnejšie nahradit’ pojmom „turizmus“. V našom geografickom priestore je vhodné tiež rozlišovat' medzi turizmom a turistikou, ako sme učinili na konci prvej časti tohto textu, kde sme upozornili na iný, tradičný význam termínu ,turista“v českom i slovenskom kontexte. 
Prvé zmienky o sociológii turizmu a vymedzenia tejto disciplíny pochádzajú od nemeckých autorov, prvým špecificky sociologickým textom o problematike bol článok Leopolda von Wieseho Fremdenverkehr als zwischenmenschliche Beziehung (Cudzinecký ruch ako medzil'udský vzt'ah) z roku 1930, prvou rozsiahlejšou sociologickou publikáciou sa stala práca H. J. Knebela Soziologische Strukturwandlungen im modernen Tourismus (Sociologické štrukturálne zmeny v modernom turizme) z roku 1960 (podl'a Cohen 1984). Skutočným prelomom však bola až kritická štúdia amerického kultúrneho historika Daniela Boorstina (1964) o „stratenom umení cestovat““ zaradená do knihy The Image, ktorá bola prvou vážnou reakciou na búrlivý rozvoj cestovania v povojnovom období, ked' sa stal turizmus naozaj masovým javom. A hoci bola Boorstinova práca zväčša kritizovaná kvôli svojím teoretickým i metodologickým nedostatkom, považuje sa za významný počiatočný impulz budovania novej disciplíny - sociológie turizmu.

O sociológii turizmu ako samostatne sa vymedzujúcej a špecializovanej sociologickej disciplíne (a nielen ako v sociológii exotickej okrajovej téme) je však možné hovorit' až od 70. rokov 20. storočia v súvislosti so štúdiami Erika Cohena, ktorého môžeme považovat' za duchovného otca tejto disciplíny. Jeho jednotlivé práce síce nepatria svojím rozsahom, híbkou analýzy či teoretickým rozpracovaním k najvýznamnejším (nie je autorom žiadnej knižnej publikácie), má však zásluhu na vzniku a rozvíjaní sociológie turizmu a na tom, že sa turizmus v posledných troch dekádach 20. storočia postupne začleňuje do spoločenskovedného akademického diskurzu ako významná črta masovej konzumnej kultúry a moderného života. ${ }^{9}$ Okrem iného Cohen ako prvý svojou typológiou turistov spochybnil všeobecne používaný pojem ,turista“ (1972); v inej práci rozvinul fenomenológiu turizmu tvrdiac, že nejde len o rôznost' rolí a typov turistov, ale tiež o rozličnost' zážitkov, podl'a ktorých je možné turistov kategorizovat' (1979). V roku 1984 publikuje štúdiu, kde zhŕňa dovtedajšie hlavné prístupy k turizmu, ktoré sa objavujú v sociologickom bádaní (turizmus ako komercializovaná pohostinnost', turizmus ako demokratizované cestovanie, turizmus ako moderný variant vol'ného času, turizmus ako moderný variant tradičného pútnictva, turizmus ako vyjadrenie základných kultúrnych tém, turizmus ako proces akulturácie, turizmus ako typ etnických vzt'ahov, turizmus ako forma neokolonializmu). V reakcii na výhrady, že t’ažkosti sociológie turizmu spočívajú aj v tom, že táto disciplína nemá vymedzené svoje vlastné „legitímne teritórium“, identifikuje štyri najfrekventovanejšie oblasti záujmu sociologického výskumu turizmu, ktorými sú: 1. turisti samotní, ich roly, motivácie, postoje a skúsenosti; 2. vzt’ahy medzi turistami a miestnym obyvatel'stvom; 3. štruktúra systému cestovného ruchu; a 4. socio-kultúrne a socio-ekonomické dôsledky turizmu. V závere tejto štúdie spred dvoch desat'ročí Cohen poznamenáva, že sociológia len nedávno objavila turizmus ako jav hodný systematického štúdia a mnohí sociológovia ju stále vnímajú podozrievavo a s určitým odstupom. Tvrdí, že to je nielen výsledok väčšinového náhl'adu sociológov na cestovanie a rekreáciu ako banálne aktivity nehodné seriózneho vedeckého záujmu, ale tiež odraz toho, že sa turizmus dosial'

9 Cohen bol od začiatkov svojho pôsobenia schopný kriticky reagovat' na podnety, ktoré akademická produkcia v oblasti disciplíny prinášala, a adekvátne ich reflektovat'. Dodnes pohotovo reaguje na aktuálne podnety, ktoré sa dotýkajú fenoménu turizmu (pozri napríklad Cohen 2005). 
neintegroval do hlavného prúdu sociologického bádania. ${ }^{10}$ Podl'a Cohena to je spôsobené hlavne tým, že konceptuálne a teoretické prístupy, ktoré sa dovtedy pri štúdiu turizmu objavili, neprešli serióznym empirickým testovaním a naopak, výskumom, ktoré sa už vtedy v pomerne vel'kom počte realizovali, chýbala explicitná teoretická orientácia, čím významnejšie neprispeli k budovaniu teórie (Cohen 1984).

Vel'mi podobné konštatovania pri analýze stavu disciplíny sociológie turizmu sa objavujú aj o 12 rokov neskôr, v úvodnej kapitole už spomenutej knihy Sociology of Tourism: Theoretical and Empirical Investigations (Sociológia turizmu: Teoretické a empirické skúmania). Editor knihy Yiorgos Apostolopoulos v nej konštatuje, že väčšina sociologických prác týkajúcich sa turizmu má len opisný charakter; tieto práce sa vyznačujú nedostatkom teoretického zakotvenia, chýba im sofistikovanejšie metodologické a štatistické spracovanie údajov a adekvátnejšie zasadenie do širšieho spoločenského kontextu. V tom vidí príčinu toho, že sociológia turizmu ako formálna sociologická špecializácia (podobne ako napríklad sociológia rodiny či sociológia vzdelávania) nebola ešte v rámci sociológie ustanovená, je v stave hl'adania akejsi všeobecnej teórie turizmu a vlastnej identity. Turizmus ako komplexný sociokultúrny, politický a ekonomický fenomén si však vyžaduje systematické sociologické skúmanie (Apostolopoulos 1996: 3-4).

Napriek týmto kritickým hodnoteniam stavu disciplíny sociológie turizmu je možné, na základe znalosti jej hlavných prác a najvýznamnejších autorov, identifikovat' hlavnú úlohu a poslanie sociológie turizmu, ktorou je štúdium vzt’ahu medzi modernitou a turizmom, tj. skúmanie hlbšieho štrukturálneho významu turizmu v modernej spoločnosti. Základným sociologickým prístupom ku skúmaniu turizmu, či už vedomým alebo nevedomým, je to, čo Wang (2000: 9) identifikuje ako „kontextualizmus modernity“. V d’alšom texte budú teda zvýraznené tie sociologické koncepcie a prístupy, ktoré poukazujú na turizmus ako na indikátor ambivalencie modernity a ktoré zvýrazňujú centralitu cestovania a pohybu v súčasnej spoločnosti.

\section{Spor o autenticitu}

Vrát'me sa do 70. rokov 20. storočia, ked' sa popri už zmieňovaných Cohenových štúdiách objavila prvá sociologická teoretická syntéza. Bola to kniha Deana MacCannella The Tourist (1976), ktorá je dodnes jednou z najvýznamnejších prác v oblasti sociológie turizmu. MacCannell bol prvým sociológom, ktorý štúdium turizmu prepojil s niektorými významnými sociologickými teóriami a pri svojej analýze využil myšlienky Durkheima, Goffmana, Lévi-Straussa a Marxa. Prínosom práce nie je len to, že je sociologickou analýzou turistu, tj. cestujúceho výletníka, účastníka zájazdu hladajúceho v rôznych konči-

10 Aj mnohí z autorov, ktorí považujú turizmus za legitímnu oblast' sociologického skúmania, sa ho snažia lokalizovat' do rámca niektorej z existujúcich disciplín. Niektorí z nich zarad’ujú turizmus pod oblast' vol'ného času, iní ho považujú za druh migrácie a turizmus študujú ako sezónnu migráciu. Cohen je predstavitel'om tretieho prúdu, ktorý konštituuje sociológiu turizmu ako samostatnú disciplínu a zvýrazňuje dôležitost' fenoménu cestovania v modernej spoločnosti (Dann a Cohen 1991: 157-158). 
nách sveta nové zážitky a skúsenosti. Jej skutočná podstata spočíva v tom, že turista je pre MacCannella modelom pre moderného človeka vo všeobecnosti a turizmus kultúrnym fenoménom, ktorý odzrkadluje štruktúru a protiklady modernity. „Naše prvé pochopenie modernej civilizácie (...) sa objavuje v mysli turistu“ (MacCannell 1976: 1). Analýza turistických atrakcií nám môže poskytnút' priamy vhl'ad do štruktúry moderného vedomia, respektíve vedomia modernity. MacCannell vidí v turistických atrakciách presnú analógiu $\mathrm{k}$ náboženským symbolom „,primitívnych l’udi““. Kl'účovým východiskom knihy je téza, že poznávacia a ideologická expanzia modernej spoločnosti je tesne a rôznymi spôsobmi spätá s moderným masovým trávením vol’ného času, zvlášt' s medzinárodným turizmom a tým, čo sa v angličtine nazýva „sightseeing“. Kniha by preto podl’a jej autora mohla „slúžit’ ako úvod do štrukturálnej analýzy modernej spoločnosti“ (1976: 3).

Hlavná téza MacCannellovej teórie sa vztahuje k téme autenticity a je polemikou s argumentmi Daniela Boorstina. V úvodnej časti tohto textu už bola spomenutá Boorstinova známa esej, v ktorej rozvinul myšlienku o pozorovanej neautenticite skúsenosti turistu. Boorstin tvrdí, že život v modernej spoločnosti je iluzórny, vykonštruovaný, nereálny, spočívajúci na „pseudoudalostiach“. Opisuje turistu ako kultúrneho ignoranta, ktorý práve preto, že žije v neautentickej odcudzenej spoločnosti plnej pseudoudalostí, sa aj počas cestovania uspokojí s neautentickým, so pseudozážitkami, s vymyslenými bezvýznamnými udalost’ami, ktoré sleduje v pohodlí dobre známeho prostredia, akým je napríklad hotelový komplex či vyhliadkový autobus (Boorstin 1964). MacCannell vychádza z podobného predpokladu ako Boorstin, jeho záver je však opačný. MacCannellova teória je založená na domnienke, že l’udia v modernej spoločnosti, ktorí vo svojom každodennom živote pri svojich bežných rutinných aktivitách zažívajú pocity odcudzenosti, povrchnosti, nepôvodnosti, straty hlbšieho zmyslu, budú v situáciách nekaždodennosti, napríklad ako turisti počas dovolenky, vyhladávat' autentickú skúsenost'. Autenticita je ústredným pojmom MacCannellovej knihy: podla neho je turista stelesnením hl'adania autenticity a toto hl'adanie je modernou verziou univerzálneho l'udského záujmu o posvätné. Turista je akýmsi súčasným pútnikom, ktorý hl’adá autenticitu v iných časoch a na iných miestach, mimo svojho každodenného života. MacCannell tu aplikuje koncepty E. Goffmana (,front region“ - javisko, tj. to, čo je prezentované oficiálne, a „back region“-zákulisie, tj. čo sa deje za scénou) a tvrdí, že turisti nachádzajú reálne a autentické práve za scénou. Ako sa však právo turistov vstupovat' „za scénu“ inštitucionalizuje, vytvárajú sa pre turistov priestory, „, ktorých sú nepravé atrakcie dekorované a prezentované ako reálne“ (Cohen 1988a: 34) a autentické. V skutočnosti preto turista väčšinou zažíva iba inscenovanú autenticitu (,staged authenticity“) a konzumuje tak len určité obrazy, dojmy a predstavy, ktoré sú pre neho vytvorené turistickým priemyslom. V konečnom dôsledku tak turista hladajúci autentickú skúsenost' zažíva neautenticitu, tá však nie je, ako tvrdí Boorstin, výsledkom spokojnosti s nepravým a iluzórnym, ale je ,štrukturálnym dôsledkom rozvoja turizmu“ (Cohen 1988a: 36).

Pojem autenticity sa stal v sociológii turizmu vel'mi vplyvným a rozšíreným, niektorí autori však začali poukazovat' aj na jeho nejasnost' a spochybňovali jeho platnost', ked’že nie všetky aktivity a zážitky turistov je možné vysvetlit' aplikovaním tohto pojmu (napríklad nakupovanie, návšteva priatel’ov, pobyt na pláži, výlet do Disneylandu a pod.) (Wang 2000). 
Aj preto Kjell Olsen (2002) píše o problematickej dichotómii medzi rolou turistu a autentickou skúsenostou, ktorá by sa mala skúmat' na úrovni ontológie, a nie epistemológie, ako je to u MacCannella, a tvrdí, že autenticita „nesmie byt' chápaná ako koncept, ktorý opisuje inherentnú črtu objektov alebo vzt’ahov, ale ako významná hodnota západného myslenia...“ (2002: 161). Podl'a Olsena stále viac turistov zist'uje, že ich situovanost' do roly turistov im znemožňuje zažit' práve to, čo hladajú. Namiesto skúmania roly turistu ako analytického konštruktu je preto treba obrátit' pozornost' $\mathrm{k}$ tomu, ako turisti samotní preživajú svoju rolu.

Mnohí autori kritizujú autenticitu v podaní MacCannella za to, že jej prisudzuje črtu akejsi danej objektívnej kvality, ktorou môže byt' posudzovaná určitá udalost', produkt či zážitok turistu. Väčšna $\mathrm{z}$ nich sa prikláňa $\mathrm{k}$ chápaniu autenticity ako sociálne konštruovaného pojmu. Jedným z týchto autorov je E. Bruner (1994), ktorý identifikuje štyri významy autenticity a na príklade New Salemu, rekonštruovanej obce z roku 1830, tj. z čias, ked' v nej pôsobil budúci americký prezident Abraham Lincoln, ukazuje, ako sa autenticita pôsobením sociálnych procesov konštruuje a znovuvytvára. Prvý význam autenticity chápe v zmysle historickej podobnosti, ked’ je nejaký objekt podobný originálu do tej miery, že je vierohodný, presvedčivý. O nejakej ulici alebo časti mesta môžme preto povedat', že vyzerá ako v 17. storočí. Druhý význam je v zmysle pôvodnosti, historickej presnosti, vernosti. V tomto prípade môžeme o ulici vyhlásit', že vyzerá presne tak, ako tá ulica vyzerala v 17. storočí, je jej vernou kópiou. $\mathrm{V}$ tret'om prípade autenticita znamená originál ako protiklad ku kópii. Ide o originálny a pravý objekt, tj. napríklad o ulicu či budovu, ktorá pochádza priamo zo 17. storočia. $\mathrm{V}$ tomto zmysle nemôže byt' žiadna reprodukcia autentická. Bruner poznamenáva, že MacCannellove chápanie autenticity korešponduje práve s týmto významom (1994: 408-409). V štvrtom význame sa autenticita vztahuje k moci, ktorá legalizuje, certifikuje, respektíve činí niečo právoplatným. Takúto formu moci predstavuje napríklad štátna autorita, pamiatkový úrad. Tu sa pojem autenticity mieša s pojmom autority. Otázkou je, kto má moc a autoritu rozhodovat', ktorá verzia histórie bude prijatá ako správna či autentická. Tento význam autenticity môže vystúpit do popredia v časoch historického prehodnocovania či zmeny režimu, čo je problém, ktorému (nielen) po roku 1989 museli čelit' aj u nás niektoré múzeá, výstavy a exponáty.

Aj E. Cohen (1988b) sa prikláňa k chápaniu autenticity ako sociálne konštruovaného pojmu, ktorého význam nemusí byt' raz a navždy daný. Podl'a neho sa autenticita môže v čase vyvíjat'. Nejaký kultúrny produkt alebo znak, pôvodne pre dané prostredie neautentický, môže postupom času nadobudnút' status autenticity. Tento proces Cohen pomenúva pojmom objavujúca sa autenticita (emergent authenticity) a ako príklad uvádza remeselné výrobky, ktoré sú pôvodne vyrábané len pre návštevníkov a turistov, ktoré sa ale môžu niekedy stat' autentickými, reprezentujúcimi nejakú etnickú skupinu či región. Poukazuje na to, ako sa americké Disneylandy, donedávna považované za exemplárne príklady vyumelkovanej popkultúry, stávajú súčast'ou súčasnej americkej kultúry a predpovedá, že v budúcnosti môžu byt' historikmi a etnografmi považované za súčast' autentickej americkej tradície (Cohen 1988b: 379-380). Príkladom objavujúcej sa autenticity zo slovenského prostredia môžu byt' bábiky vyrábané z kukuričného šúpolia, ktoré si turisti s vel'kou oblubou kupujú na Slovensku ako tradičný l'udový výrobok a ani väčšina domácich obyvatel'ov netuší, že ide o produkt vymyslený výtvarníčkou Ústredia l'udovej umeleckej výroby z prelomu 50. a 60. rokov 20. storočia (Akácsová 2005). ${ }^{11}$ 
N. Wang (2000: 48-50) rozlišuje medzi tromi druhmi autenticity - objektívnou, konštruovanou a existenciálnou. Prvé dva druhy autenticity sú podla neho zamerané len na posudzovanie objektov: objektov ako originálu v prípade objektívnej autenticity, kde sú kritériá absolútne a objektívne dané (takto ju chápu Boorstin a MacCannell), alebo objektov, ktorým je status autenticity pripísaný. Autenticita je tu sociálne konštruovaná, relatívna, ako je to v prípade konštruovanej autenticity (reprezentovanej prístupmi Brunera i Cohena), v rámci ktorej turisti hl’adajú znaky autenticity alebo symbolickú autenticitu. ${ }^{12}$ Tieto dva druhy autenticity sú však podla Wanga nedostačujúce: autenticita nie je záležitost'ou bud'/alebo ako to vyplýva z objektívnej autenticity, ale zahŕňa ovel’a širšie spektrum; s realitou má málo spoločné i „,projekcia určitých stereotypizovaných obrazov cirkulujúcich v médiách a reklamných brožúrach západných spoločností“ (2000: 54), z ktorých sa odvodzuje konštruovaná autenticita. Preto Wang zavádza pojem existenciálnej autenticity, ktorá sa „vzt’ahuje k potenciálnemu existenciálnemu stavu bytia vyvolaného aktivitami turistu“ (2000: 49). Počas tejto skúsenosti l'udia pocit'ujú stav výraznejšej autenticity a slobodnejšieho sebavyjadrenia, než aký zažívajú v každodennom živote, čo nesúvisí s mierou autenticity navštevovaných objektov, ale skôr s tým, že sú zapojení do nekaždodenných, nie bežných aktivít, ktoré stoja $\mathrm{v}$ protiklade $\mathrm{k}$ obmedzeniam bežného života (2000: 50).

Vhodnou ilustráciou Wangovho konceptu existenciálnej autenticity môže byt' štúdia Lori Holyfield (2002) uverejnená v časopise Biograf. Autorka tu opisuje výskum, ktorý uskutočnila $\mathrm{v}$ prostredí spoločností zaoberajúcich sa komerčným raftingom na divokej vode. Kladie si otázku, či je možné zažit' skutočné dobrodružstvo (mohli by sme ho nazvat' autentickým) v prostredí, kde sa toto dobrodružstvo vyrába, inscenuje a kde sa zážitky ponúkajú na predaj. Prichádza k záveru, že „činnosti, ktorými by skúsený hl’adač rizika mohol opovrhnút', sa nakoniec pre nováčika stávajú základnou prísadou dobrodružstva“ (Holyfield 2002: 26). „Ak existuje príslušný sociálny kontext, potom môžu emócie, ktoré pocit'ujeme v situáciách neurčitosti, naše zážitky ešte d’alej umocňovat', dokonca i v komerčnom prostredi““ (2002: 27).

Ako výstižný príklad autentického zážitku konkrétneho turistu priamo „, teréne“ môže slúžit' nasledujúci úryvok - osobná a vel'mi spontánna výpoved’ zo seminárnej práce študentky, ktorá $\mathrm{z}$ hl'adiska vlastnej skúsenosti a na základe pochopenia problematiky autenticity na seminári zo sociológie turizmu (vedeného autorom tohto príspevku) napísala:

11 Podobnými príkladmi sú aj mnohé drevené výrobky a ich „tradičné“ vzory či textilné výrobky (figurálna šopornianska výšivka, modrotlač atd’.), ktoré sa dnes automaticky považujú za typický slovenský l'udový prejav (Akácsová 2005). Nakoniec aj „tradičné slovenské národné jedlo“ - bryndzové halušky - nie sú jedlom, ktoré by slovenskí rol’níci konzumovali odjakživa, ked’že sa zemiaky potrebné na výrobu halušiek masovejšie rozšírili na Slovensku ako základ stravy až od začiatku 19. storočia.

12 Culler komentuje, ako turisti po celom svete hl’adajú ,znaky francúzskosti, typického talianskeho správania, ukážkových orientálnych scén, typických amerických dial’nic, tradičných anglických pubov“ (citované podl'a Rojek a Urry 1997: 9). 
Minulý rok cez prázdniny som so známymi navštívila v anglickom Doveri tajné tunely v útesoch, ktoré počas druhej svetovej vojny slúžili ako úkryt a zachránili vel'ké množstvo l’udských životov. Človek si povie - čo už len mohlo byt' na tuneloch také zaujímavé, na mňa však urobili vel'ký dojem. Prečo? Kráčate tunelmi, ktoré sú osvetlené lampami, počujete hlasy l’udí a vidíte predmety: stoličky, stoly, taniere, v nich jedlo, rozohraný šach, noviny, postele... Kráčate d’alej, zrazu niekde nad vami hučia lietadlá, počujete zvuk padajúcich bômb, svetlo zabliká, hlasy sú nervóznejšie. Kráčate d’alej, zostupujete po schodoch na nižšiu úroveň, do d’alšej vrstvy spletitých chodieb. Vstúpite do miestnosti, v ktorej sú operačné nástroje, hlasy, sú vel'mi nervózne a je ich tu vel’a, prikazujú podávat' nožnice, skalpel, vatu... Vidíte nádobu, v ktorej je krvavý obväz, opät' počut' lietadlá, svetlá zablikajú, svietia, hlasy s úl'avou pokračujú v koordinácii operácie... svetlo zhaslo, nervozita. Stojíte v tme a s hrôzou zistujete, že ste v operačnej miestnosti počas druhej svetovej vojny a prekážate, máte pocit, že do vás niekto narazil. Zdravotná sestra? v tme počujete len hlasy, nikoho nevidíte, niekto kričí, aby ste odtial'to odišli, pretože prekážate, váhate, či skutočne neodíst', $v$ tom sa zapne svetlo, ste v miestnosti s operačnými nástrojmi, okolo sú vaši známi, hlasy sa upokojili... Nie ste uprostred operácie a nie je ani druhá svetová vojna. Ste v múzeu.

Zažili ste v tomto prípade autentický zážitok? Čo bolo na tomto pôvodné? Jedine tie tunely, v ktorých ste sa prechádzali. A možno niektorý z tých predmetov, určite nie všetky, jedlo bolo umelé, svetlo sa regulovalo, hlasy nahovorili herci, krv bola farbou... len vel'mi malá pôvodnost', čo poviete? Ale svoj dojem ako zážitok to vo mne zanechalo, necestovala som zbytočne!

Naša exkurzia po rôznych vymedzeniach a chápaniach pojmu autenticity nás vedie k uzáveru, že autenticitu vo väčšine situácií nie je možné chápat' ako objektívne kritérium, ktoré môžme aplikovat' na jednotlivé udalosti, objekty a aktivity ponúkané turistickým priemyslom a ktorým by sme mohli merat' kvalitu zážitku individuálnych turistov. Rôzni l’udia sa navyše budú líšit' vo svojom posudzovaní autenticity, čo vyplýva napríklad aj z ich doterajších skúseností, očakávaní, vzdelania, vzt’ahu k posudzovanému objektu, prostredia, z ktorého pochádzajú, i miery odcudzenia, ktoré vyplýva z podmienok života v modernej spoločnosti a je pocit'ované rôznymi l'ud'mi rôzne. Wangov koncept existenciálnej autenticity navyše hovorí, že hl'adanie autenticity a autentický zážitok sú možné aj v úplne neautentickom prostredí a závisia od aktivít samotných turistov. V západných krajinách vzrastá tiež podiel turistických aktivít (dobrodružný turizmus, hobby turizmus, návšteva priatel'ov, aktivity v prírode, plavba na mori), ${ }^{13} \mathrm{kde}$ je pre turistu dôležitá skôr autenticita jeho vlastného ja alebo intersubjektívna autenticita a otázka autenticity okolitých objektov a prostredia hrá menšiu rolu (Wang 2000: 70-71). Čo však od čias prvého vydania MacCannellovho (1976) ústredného diela pretrváva, je význam pojmu autenticity pre sociologické štúdium turizmu a moderného človeka vôbec. Hl'adanie autenticity zostáva základom turistickej motivácie a turizmus je ,(...) jednou z foriem hl'adania autenticity v odpovedi na štrukturálnu neautenticitu modernity“ (Wang 2000: 71).

\section{Syndróm turistu}

Podobný význam ako MacCannellov The Tourist mala pre rozvoj sociologického uvažovania o turizme aj práca Johna Urryho The Tourist Gaze (Pohl'ad turistu), ktorá vyšla prvýkrát na začiatku 90. rokov. Aj Urry vychádza z predpokladu, že byt' turistom je jednou z charakteristic-

13 Na rozdiel od západných krajín tvorili spomínané turistické aktivity vždy významnú zložku fenoménu cestovania v česko-slovenskom kontexte. Za túto pripomienku (i niekol'ko iných) d’akujem recenzentom tohto textu. 
kých čŕt modernej skúsenosti a významným statusotvorným činitelom modernej spoločnosti. ${ }^{14}$ Práve koncept turistovho pohl’adu je pre neho zástupným pojmom, ktorý zhŕňa skúsenost' turistov a je interpretáciou toho, čo rôzni turisti (z rozličných sociálnych skupín, v odlišných spoločnostiach a obdobiach) hl'adajú a čo robia počas dovolenky, tj. času mimo prácu, povinnost' a každodennost'. Termínu ,pohl'ad“ (gaze) je treba rozumiet' ako pojmu, ktorý zahíňa spôsob nazerania na svet a ktorý zároveň dáva podobu tomu, čo je videné, a definuje prevládajúci spôsob nazerania. „Pohl'ad turistu“ nám teda môže interpretovat' celý spôsob života v určitom období, ked’že ,je konštruovaný vo vztahu k svojmu náprotivku, k ne-turistickým formám sociálnej skúsenosti a vedomia“ (Urry 1991: 1). Ked’že cestovanie a pobyt niekde „,inde“, v priestore a čase nekaždodennosti, počas rekreácie, dovolenky alebo prázdnin je kontrastom $\mathrm{k}$ bežnému, obyčajnému a znamená dočasné prerušenie zabehanej rutiny a každodenných praktík, tak vymedzenie typických objektov „pohl'adu turistu“ nám môže pomôct' odhalit' tie aspekty „normálnej“ spoločnosti a jej bežných praktík a spôsobov, ktoré by nám ináč ostali skryté (Urry 1991). ${ }^{15}$

Podobným spôsobom uvažuje o vol'nočasových aktivitách aj Chris Rojek. Na základe štúdia prác Eliadeho, Durkheima či Evansa-Pritcharda o opakujúcich sa kolektívnych rituáloch l'udí v tradičných spoločnostiach, ktorých ciel'om je dočasná cesta „preč“ z normality, si všíma, že aj v súčasnej kultúre vol'ného času (culture of leisure) je prítomný silný transgresívny prvok. Vol’nočasové aktivity nám umožňujú „objektivizovat’ pravidlá a zvyky každodenného života a podriadit' ich kritickému prehodnoteniu“ (Rojek 2000: 20).

Urry koncepčne rozlišuje medzi dvoma základnými druhmi turistovho pohladu: romantickým a kolektívnym. Ak má byt' kvalita romantického pohl’adu zachovaná, nesmie byt' prekročená určitá percepčná kapacita, tj. množstvo návštevníkov daného miesta, aj ked’ ešte nemusí byt' presiahnutá jeho fyzická kapacita (tj. fyzicky by tam ešte išlo umiestnit' viac l'udí). Uvedené rozlíšenie sa vzt'ahuje hlavne na prírodné atraktivity, tj. hory, lesy, odl'ahlejšie pláže a podobne, kde sa kladie dôraz na samotu, súkromie, pokoj, spätost's prírodným objektom: vtedy je zážitok z daného miesta intenzívnejší a hlbší; naopak, ak sa na uvedených miestách nachádza viac l'udí, značne sa znižuje kvalita zážitku. Obrazy evokujúce romantický pohl’ad sú vel'mi často využívané najmä v západnej kultúre pri reklame a marketingu určitých turistických destinácií. Kolektívny pohl'ad sa vyznačuje inými charakteristikami a je založený na tom, že určité miesta by vyzerali zvláštne, ak by boli prázdne (ako sa to udialo v prípade niektorých prímorských letovísk, napríklad v Anglicku či Nemecku). Sú to vlastne iní ludia, ktorí vytvárajú prít’ažlivost' takýchto miest, dávajú im atmosféru a istým spôsobom karnevalový kolorit. Je to tiež prípad niektorých vel'kých miest, ktorých unikátnost' spočíva v ich kozmopolitnom charaktere (Londýn, Sydney, Hongkong, ale i Las Vegas), či oblúbených prímorských destinácií (Ibiza) (Urry 1991: 44-46).

14 Na inom mieste Urry poukazuje na to, ako sú súčast'ou dnešnej spoločnosti extenzívne formy mobility, aké sú významné v procese konštituovania sociálneho a ekonomického života a ako mnohé formy sociálneho kapitálu závisia na extenzívnom cestovaní. Procesy, ktoré vedú k redukcii mobilít, často oslabujú sociálny kapitál a vytvárajú nové formy sociálnej exklúzie (Urry 2002b: 263-265).

15 Termín „gaze“ má u Urryho zjavne aj foucaltovskú inšpiráciu a znamená nielen pohl’ad, ale i dohl'ad - v tom zmysle, že pohl'ad turistu je systematizovaný a sociálne organizovaný profesionálnymi expertmi, ktorí majú vplyv a dohl’ad nad tým ako sa pohl’ad nás ako turistov konštruuje a rozvíja. 
V novom vydaní The Tourist Gaze (2002a: 150-151) Urry dopíňa, na základe pripomienok iných autorov, svoje dva druhy turistovho pohl'adu d’alšími: diváckym, ktorý zahŕňa kolektívny letmý pohl'ad, napríklad z okna autobusu; posvätným, ktorý opisuje sústredený pohl'ad a koncentráciu pozornosti veriaceho nachádzajúceho sa na posvätnom mieste; antropologickým, pri ktorom návštevník skúma rôznorodé miesta a pamiatky a je schopný ich interpretovat' (bud' sám alebo za pomoci sprievodcu) v kontexte rôznych historických a interkultúrnych významov a symbolov; environmentálnym, ktorý zahŕn̆a skúmanie vplyvu rozličných turistických praktík na prostredie a na základe tejto reflexie je schopný vybrat' a doporučit' tie s minimálnym dopadom na životné prostredie; a mediálnym pohl'adom, v ktorom sú jednotlivé miesta predmetom kolektívneho pohl’adu vd’aka svojej medializácii alebo istej mediálnej udalosti, ktorá sa tam odohrala. Príkladom sú miesta nakrúcania známych filmov či seriálov. Kedysi mladé ženy putovali do jednej z kanadských provincií, kde vyrastala Anna zo Zeleného domu, prípadne hladali miesta v Atlante, kde žila Scarlett, hlavná hrdinka románu Odviate vetrom. V súčasnosti sa každý týždeň stovky l'udí zúčastňujú v New Yorku na prehliadke tých lokalít, manhattanských barov a kaviarní, ktoré tvorili kulisy seriálu Sex v meste (Čobejová 2005). Iným trendom týkajúcim sa európskej turistiky sú zájazdy po stopách $D a$ Vinciho kódu. ${ }^{16}$

V jednej zo svojich najnovších prác sa Urry (2000) venuje mobilite v širšom zmysle, hovorí o rôznych druhoch cestovania - fyzickom cestovaní, o mobilitách objektov, o imaginatívnom cestovaní a o virtuálnom cestovaní. Zdôrazňuje, že mobilita - ako metafora aj ako proces - je podstatou súčasnej spoločnosti, a preto by mala byt' ústrednou témou sociologickej analýzy (tu možno nájst' niektoré podobnosti s prístupom Maffesoliho). Poukazuje na dôležitost' týchto mobilít, na pohyb l'udí, objektov, obrazov a informácií, ktoré tak produkujú a reprodukujú spoločenský život a kultúrne formy. Kultúry samotné sú mobilné, čo je výsledkom mobilít, ktoré podporujú rôznorodost' spoločenského života (Urry 2000).

Značná mobilita a formy mobility majú radikálny vplyv na to, ako ludia zažívajú a poznávajú svet, ako sa u nich menia formy subjektivity a sociability. Mobility v súčasnosti vytvárajú sociálny život ako taký, nielen život turistu. Práve preto má ale mnoho poznatkov získaných skúmaním turizmu ovel'a širšiu platnost', ale tiež podl'a Urryho implikuje, že mnohé takzvané turistické miesta už nie sú len diferencovanými miestami, ktoré sú vyhradené turistom. Dochádza k tomu, čo Urry nazýva dediferenciáciou medzi turizmom a ostatnými sférami života (Urry 1995, 2002; Franklin 2001). Súčasná podoba kapitalizmu je epochou, v ktorej sa rozpúšt’a špecifickost’ turizmu, „l'udia sú turistami po väčšinu svojho času, či už sú v danej situácii doslova mobilní, alebo len zažívajú simulovanú mobilitu prostredníctvom neuveritel'nej premenlivosti bezpočetných znakov a elektronických imidžov“ (Urry 1995: 148). Turizmus ako predtým zvláštna a jednoznačne identifikovatel'ná sféra spoločenských aktivít vyskytujúca sa $\mathrm{v}$ stanovenom čase a priestore sa v poslednej dobe stále viac mieša $\mathrm{s}$ inými spoločenskými aktivitami (nakupovanie, sledovanie médií, športové a kultúrne aktivity atd'.) do tej miery, že mnoho l'udí sa stáva turistami po väčšinu svojho času (Sharpley 1996). ${ }^{17}$

16 Len v samom Paríži ponúkajú takéto prehliadky najmenej tri cestovné kancelárie, každá z nich sa zameriava na iné aspekty Brownovej knihy („Nový trend v európskej turistike“, SME Vikend, august 2005). 
Vel'mi podobne (aj ked' iným, metaforickejším jazykom) reflektuje rolu turistu Zygmunt Bauman (1993a, 1993b, 1999), aj ked', na rozdiel od MacCannella a Urryho, nie je autorom knihy, ktorá by bola venovaná výhradne turistovi či fenoménu turizmu. Bauman podobne ako MacCannell a Urry tvrdí, že turista je stelesnením a metaforou súčasného života v období ako ju Bauman nazýva - tekutej modernity (Bauman 2002). Má na mysli určité aspekty skúsenosti turistu, napríklad vedomie o dočasnosti svojho pobytu na určitom mieste, neprináležitosti $\mathrm{k}$ tomuto miestu, ktoré sa stáva existenciálnou skúsenost’ou človeka všeobecne. Ten si je vedomý dočasnosti svojho pôsobenia na určitom mieste, strieda pracovné úväzky i súkromné záväzky, prechodné bydliská a domovy bez úmyslu niekde sa trvalejšie usadit'. Často k pohybu nepotrebuje ani vyjst' zo svojho bytu, stačí ked' sa preplieta webovými stránkami pochádzajúcimi z opačných kútov sveta, ked’ prepína kanály satelitnej televízie. „Skáčeme do neznámych priestorov a zase von rýchlost'ou značne prevyšujúcou možnosti nadzvukových lietadiel (...), ale nikde nezostávame tak dlho, aby sme sa stali niečím viac než návštevníkmi a cítili sa chez soi“ (Bauman 1999: 95). Tieto a podobné charakteristiky súčasného života, z ktorých za najdôležitejšie považuje vol’nost' väzieb a život pre danú chvílu, nazýva Bauman syndrómom turistu. Aj podl'a neho je pre sociológov, bez ohl'adu na to, akou oblast'ou l'udskej spoločnosti sa zaoberajú, pádnym dôvodom študovat' skúsenost' turistu, ked'že v čistej podobe vyjavuje to, čo je v bežnom živote väčšinou nejasné a zastreté (Bauman in Franklin 2003: 207-208).

\section{Záver}

Turista a spôsoby spotreby turistu sú emblémami mnohých čŕt súčasného moderného života, napríklad mobility, nepokoja, hl’adania autentického, hladania úniku (Franklin a Crang 2001: 19), vol'ného času, hry a zábavy, demonštratívnej spotreby atd'. Ciel'om tohto textu bolo zdôraznenie širšieho kultúrneho, globálneho a ideologického významu organizovaného turizmu v západnej civilizácii. Podl’a Johna Urryho bol rok 1840 medzníkom, ktorý priniesol významné zmeny vo vtedajšom svete a nezvratne ustanovil nové vzorce spoločenských vzt’ahov. Bol to moment, kedy „turistov pohl'ad, tá zvláštna kombinácia prostriedkov kolektívneho cestovania, túžby po cestovaní a techník fotografickej reprodukcie sa stala klúčcovým komponentom západnej modernity“ (Urry 2002a: 148). Aj preto Urry tvrdí, že by sa malo v týchto súvislostiach možno menej hovorit' o fordizme a viacej o cookizme, pretože systém organizácie pohybu obrovského množstva l'udí na mnohopočetných územiach považuje za významnejší a t’ažšie uskutočnitel'ný výdobytok než vyrábanie vel'kého množstva produktov na jednom mieste (Urry in Franklin 2001). Mnohé javy spojené s cestovaním sa vo vzrastajúcej miere stávajú ústrednými pre ekonomickú reštrukturalizáciu, globalizáciu a estetizáciu každodenného života, dochádza k procesu „turistifikácie“, v rámci ktorého spoločnost' začleňuje turizmus do svojho ekonomického a sociokultúrneho systému. Miestami turistickej spotreby sa stávajú transformované sféry kultúry, identity, krajiny, historického dedičstva a urbánneho priestoru (Franklin a Crang 2001, Wang 2000). Turista sa čím d’alej tým viac stáva symbolom sveta, v ktorom žijeme.

17 Urry (1995) uvádza ako jeden z príkladov tohto procesu nebývalý rozmach reštaurácií, ktorých počet sa len v USA medzi rokmi 1960 a 1980 viac než zdvojnásobil. Íst' niekam do reštaurácie na večeru sa ešte pred 30 rokmi nepovažovalo za bežné a bolo vyhradené len pre obdobie dovolenky. 


\section{Literatúra}

Akácsová, E. 2005. „Stratil l’ud cit pre umenie?“ Týždeň, 26. September: 60-63.

Apostolopoulos, Y. A kol. (eds.) 1996. Sociology of Tourism: Theoretical and Empirical Investigations. London and New York: Routledge.

Apostolopoulos Y. 1996. „Introduction. Reinventing the Sociology of Tourism.“ In Y. Apostolopoulos a kol. (eds.) Sociology of Tourism: Theoretical and Empirical Investigations. London and New York: Routledge, s. 1-12.

Bauman, Z. 1993a. Úvahy o postmoderni době. Praha: Sociologické nakladatelství.

Bauman, Z. 1993b. Postmodern Ethics. London: Routledge.

Bauman, Z. 1999. Globalizace. Di̊sledky pro člověka. Praha: Mladá fronta.

Bauman, Z. 2002. Tekutá modernita. Praha: Mladá fronta.

Bell, C. 2002. „The Big ,OE‘: Young New Zealand Travellers as Secular Pilgrims.“ Tourist studies, 2 (2): 143-158.

Berghoff, H. A kol. (eds.) 2002. The Making of Modern Tourism: The Cultural History of the British Experience, 1600-2000. Palgrave Publishers Ltd.

Berghoff, H., Korte, B. 2002. „Britain and the Making of Modern Tourism. An Interdisciplinary Approach." In H. Berghoff a kol. (eds.) The Making of Modern Tourism: The Cultural History of the British Experience, 1600-2000. Palgrave Publishers Ltd., s. 1-20.

Boorstin, D. 1964. The Image: a Guide to Pseudo-Events in America. New York: Harper \& Row. Bruner, E. M. 1994. „Abraham Lincoln as Authenthic Reproduction: a Critique of Postmodernism.“ American Anthropologist, 96: 397-415.

Cohen, E. 1972. „Toward a Sociology of International Tourism.“ Social Research, 39: 164-182.

Cohen, E. 1979. „A Phenomenology of Tourist Experiences.“ Sociology, 13: 179-201.

Cohen, E. 1984. „The Sociology of Tourism: Approaches, Issues, and Findings. Annual Review of Sociology, 10: 373-392.

Cohen, E. 1988a. „Traditions in the Qualitative Sociology of Tourism.“ Annals of Tourism Research, 15: 29-46.

Cohen, E. 1988b. „Authenticity and Commodization in Tourism.“ Annals of Tourism Research, 15: 371-386.

Cohen, E. 2005. ,Tourism and Disaster: The Tsunami Waves in Southern Thailand.“ In W. Alejziak, R. Winiarski (eds.) Tourism in Scientific Research. Kraków: Academy of Physical Educatrion, s. 81-114.

Crick, M. 1996. „Representations of International Tourism in the Social Sciences: Sun, Sex, Sights, Savings, and Servility.“ In Y. Apostolopoulos a kol. (eds.) Sociology of Tourism: Theoretical and Empirical Investigations. London and New York: Routledge, s. 15-50.

Čobejová, E. 2005. „Seriál sa končí. Vydajte sa!“ Týždeň, 14. marec 2005: 48-49.

Dann, G., Cohen, E. 1991. „Sociology and Tourism.“ Annals of Tourism Research, 18: 155-169.

Franklin, A. 2001. „The Tourist Gaze and Beyond: An Interview with John Urry.“ Tourist studies, 1: 115-131.

Franklin, A. 2003. „The Tourist Syndrome: An Interview with Zygmunt Bauman.“ Tourist studies, 3: 205-217.

Franklin, A.; Crang, M. 2001. „The Trouble with Tourism and Travel Theory?“ Tourist studies, 1: 5-22. 
Gúčik, M. A kol. 2004. Krátky slovník cestovného ruchu. Banská Bystrica: Slovensko-švajčiarske združenie pre rozvoj cestovného ruchu.

Holyfield, L. 2002. „Jak se vyrábí dobrodružství: Vzrušení na prodej.“ Biograf 28: 5-30.

Chard, Ch. 2002. „From the Sublime to the Ridiculous: The Anxieties of Sightseeing.“ In H. Berghoff a kol. (eds.)The Making of Modern Tourism: The Cultural History of the British Experience, 1600-2000. Palgrave Publishers Ltd., s. 47-68.

Jafari, J. 1982. „Comment.“ Current Anthropology, 21: 137.

Krippendorf, J. 1986. „Tourism in the System of Industrial Society.“ Annals of Tourism Research, 13: 517-532.

Librová, H. 1994. Pestři a zelení (Kapitoly o dobrovolné skromnosti). Brno: Veronica a Hnutí Duha.

MacCannell, D. 1976. The Tourist: a New Theory of the Leisure Class. London: Macmillan.

Maffesoli. M. 2002. O nomádství: Iniciační toulky. Praha: Prostor.

Martin, G. 2002. „New Age Travellers: Uproarious or Uprooted?“ Sociology, 36 (3): 723-735.

Olsen, K. 2002. „Authenticity as a Concept in Tourism Research.“ Tourist studies, 2: 159-182.

Przeclawski, K. 1979. Socjologiczne problemy turystyki. Warszawa.

Przeclawski, K. 1984. Turystyka a czlowiek i spoleczeństwo. Warszawa: Instytut Wydawniczy Zwiazków Zawodowych.

Przeclawski, K. 1996. Czlowiek a turystyka. Zarys socjologii turystyki. Kraków: Albis.

Rojek, C. 2000. Leisure and Culture. Houndmills, Basingstoke, Hampshire and London: Macmillan Press Ltd.

Rojek, C., Urry, J. 1997. „Transformations of Travel and Theory.“ In C. Rojek, J. Urry (eds.)

Touring Cultures: Transformations of Travel and Theory. London a New York: Routledge.

Sharpley, R. 1994. Tourism, Tourists \& Society. Huntingdon: ELM Publications.

Sharpley, R. 1996. „Tourism and Consumer Culture in Postmodern Society.“ In: M. Robinson,

N. Evans, P. Callaghan (eds.) Tourism and Cultural Change. The Centre for Travel and Tourism.

Sørensen, A. 2003. „Backpacker Etnography.“ Annals of Tourism Research, 30: 847-867.

Urry, J. 1991. The Tourist Gaze. London, Thousand Oaks and New Delhi: Sage.

Urry, J. 1995. Consuming Places. London and New York: Routledge.

Urry, J. 2000. Sociology Beyond Societies: Mobilities for the Twenty-first Century. London and

New York: Routledge.

Urry, J. 2002a. The Tourist Gaze. Second Edition. London, Thousand Oaks and New Delhi: Sage.

Urry, J. 2002b. „Mobility and Proximity.“ Sociology, 36: 255-274.

Valentová, M. 2001. „Turismus a autenticita.“ Biograf, 25: 105-115.

Velký sociologický slovník. 1996. Praha: Karolinum.

Verdon, J. 2003. Volný čas ve středověku. Praha: Vyšehrad.

Wang, N. 2000. Tourism and Modernity: a Sociological Analysis. Oxford: Elseviere Science Ltd. 


\section{Autor}

Ivan Chorvát pôsobí od roku 1995 na Univerzite Mateja Bela v Banskej Bystrici, v súčasnosti pracuje na tamojšom Ústave vedy a výskumu. Okrem výskumu sa venuje tiež pedagogickej činnosti v rámci vedenia kurzov Introduction to Sociology, Sociológia turizmu, Životný štýl v súčasnej spoločnosti a Kultúrna a sociálna antropológia. Je autorom monografie Muž - otec $v$ súčasnej rodine a editorom zborníka Premeny rodiny v urbánnom prostredí. Zameriava sa na sociologické skúmanie rodiny, turizmu a na štúdium sociologických teórií. Kontakt: Ivan.Chorvat@umb.sk 